\title{
A Review of Refugees' Access to Health Insurance in the USA Huaibo Xin
}

Department of Applied Health, Southern Illinois University Edwardsville, Campus Box 1126, SIUE, Edwardsville, IL62026, USA

Article Details
Article Type: Review Article
Received date: $21^{\text {st }}$ April, 2018
Accepted date: $17^{\text {th }}$ July, 2018
Published date: $31^{\text {st }}$ August, 2018
"Corresponding Author: Huaibo Xin, Department of Applied Health, Southern Illinois University Edwardsville, Campus
Box 1126, SIUE, Edwardsville, IL62026, USA E-mail: hxin@siue.edu
Citation: Xin H (2018) A Review of Refugees'Access to Health Insurance in the U.S. J Pub Health Issue Pract 2: 119. doi:
https://doi.org/10.33790/jphip1100119.
Copyright: O2018, This is an open-access article distributed under the terms of the Creative Commons Attribution License
4.0, which permits unrestricted use, distribution, and reproduction in any medium, provided the original author and source are
credited.

\begin{abstract}
Current literature indicates an increased disease burden among refugees resettled worldwide as well as in the U.S. Both prevalence and incidence of infectious diseases, chronic diseases, and health conditions are high or higher compared to the general American population. The question raised is how well refugee populations have been responding to their medical expenses. The purpose of this study is through a systematic literature review to identify the challenges of accessing health insurance among U.S. refugees, and to advocate for a healthcare policy change. More than 400 peerreviewed journal articles and book chapters obtained from major databases, and published between 2005 and 2018 were reviewed. Fourteen articles related to the U.S. refugees and health insurance, were included in the final analysis. Seven themes emerged. Results suggested that (1) Compared to the general or minority populations, U.S. refugees were more likely to be uninsured or underinsured; (2) Refugees demonstrated the unaffordability of medical co-payments; (3) There was a lack of full coverage of medical needs; (4) There was a lack of affordable private insurance plans; (5) There was a lack of understanding of the U.S. health insurance application; (6) U.S. refugees struggled to navigate both government and private health insurance; And (7) Refugees had difficulty in understanding the U.S. healthcare policies. More research is needed to specifically examine the accessibility and affordability of health insurance among multiethnic refugee populations in the U.S. Social determinants (e.g., employment, education, and income) should also be addressed in consideration of getting refugees fully insured.
\end{abstract}

Key Words: Disease Burden, Refugees, Healthcare, Health Insurance.

\section{Introduction}

There has been an increased burden of both communicable and noncommunicable diseases among refugees either overseas or in the U.S. [1-22]. In 1999, 2,545 refugees resettled in Minnesota from Eastern Europe, Southeast Asia, and Sub-Saharan Africa at all ages were screened for tuberculosis, hepatitis B, and parasites. About $49 \%$ of the tested had a strong positive tuberculosis response with being higher in men and adults and the highest in Ethiopian refugees followed by refugees from Vietnam, Somalia, Bosnia and Herzegovina, Ukraine, and Liberia [1]. About $7 \%$ of the refugees had hepatitis B surface antigen positive, and $30 \%$ of the refugees younger than 18 years old were tested positive for one or more types of parasites [1].
Overseas screening for tuberculosis among 378,506 refugees who arrived in the U.S. from 1999 to 2005 from countries, including Ukraine, Vietnam, Somalia, Sudan, Bosnia and Herzegovina and others, as well as among 2,714,223 US-bound immigrants arrived in the U.S. during the same time period, indicated that compared to the immigrant counterparts, the refugee participants had slightly higher smear-negative tuberculosis but had 3.4 times higher inactive tuberculosis prevalence rate [2]. Hepatitis B prevalence rates during 2006 -2011 obtained from four U.S. sites among 6,175 refugees largely from Bhutan, Burma, and Iraq, and from smaller groups, including Eritrea, Ethiopia, Somalia, and the former Soviet Union, suggested that both Burmese and the multiethnic smaller refugee groups had a significantly higher prevalence rate $(43 \%$ and $40 \%$ ) than Bhutanese and Iraqi [3]. Studies also indicated a high prevalence of non-communicable and chronic diseases among U.S. refugees [4-22]. A retrospective medical record review was conducted among 180 refugees arrived in the U.S. during 2006-2010 from Middle East, South Asia, Africa, Latin America, Asia-Pacific, and Europe. For the first eight months after arrival, the medical records showed that more than half of the adults had one or more chronic non-communicable health issues, such as depression, posttraumatic stress disorder (PTSD), hypertension, dyslipidemia, and impaired vision [4]. The participants also carried the heavy burden of risk factors for chronic diseases, including obesity, obese, and smoking [4]. A recent study compared 490 refugee adults mainly came from Europe, Central Asia, Latin America, and the Caribbean and lived in the U.S. for at least one year, with 3,715 aged-matched U.S. immigrants. The findings suggested that compared to the immigrant participants, refugee participants were more likely to report a poor or fair health status, hypertension, arthritis, health disease, stroke, and behavioral health concerns [5]. Literature also emphasized a heavy presentation of mental disorders among different US-bound refugee populations across different age ranges due to pre-migration, migration, and post-migration traumas [6-8].

Recent studies further looked into individual refugee populations have also demonstrated the significance of non-communicable chronic diseases and health risks [9-22]. For instance, questions related to the information, such as health status, nutrition, and dietary knowledge, attitudes, and practices, were asked among 120 Bhutanese refugee women aged 18-65 years resettled in Northeast Ohio. More than $60 \%$ of the participants lived in the U.S. for less than 2 years. The prevalence rates of self-reported overweight and/or obesity, 
asthma, hypertension, diabetes, heart disease and cancer among women aged 40 and older were greatly higher compared the younger age group with the highest rate of being hypertension (42\%). More than half of the women were measured being overweight or obese $2009-2010$ also indicated that $59 \%$ of the patients had at least one chronic disease, $52 \%$ of them had overweight or obesity, $23 \%$ had hypertension, along with other chronic diseases, including diabetes, Vitamin B12 deficiency, and depression [10], which are consistently with the findings from a health assessment among Bhutanese refugee adults living in Houston [11]. The health assessment also revealed inflammation of joints, and high cholesterol) [11]. Depression, anxiety, PTSD, and suicidal acts among Bhutanese refugees were as prevalent as among many other refugee populations due to persecution, separation from family, financial constraint, job dissatisfaction, and lack of social support $[12,13]$. About $56 \%$ of 497 Iraqi refugees in a study conducted in 2011 in Utah disclosed their traumatic experiences [14]. Increased pre-and post-resettlement traumas/stressors were associated with Iraqi refugees' weight development, mental disorders, and poor physical health [14-18]. Approximately, $35 \%$ of 18,990 US-bound Iraqi refugees screened between 2007 and 2009 by the International Organization for Migration had at least hypertension, diabetes, and/or obesity. Other health concerns were also reveled in this population, including vision, ear, throat, dental, hearing problems [18]. Compared to the age- and gender-adjusted rates of the general U.S. population, prevalence rates of hypertension, diabetes, hyperlipidemia, and other health problems can be significantly higher for the U.S. refugees, such as Cambodians [19, 20]. Cambodian refugees rated their health status as being unusually poor after 20 years' displacement in the U.S., which cannot be solely explained by their low socio-economic status [20]. Unsurprisingly, health concerns were exceedingly presented among African and other Southeast Asian refugee groups in different states as well $[21,22]$. The significance of the disease burden among the U.S. refugees raised the concern about how well refugee populations have been responding to their medical expenses. The purpose of this study is through a systematic literature review to identify the challenges of accessing health insurance among U.S. refugees, and to provide recommendations for a healthcare policy change.

\section{Methods}

\section{Inclusion and Exclusion Criteria}

Only peer-reviewed journal articles, reports, and book chapters that were related to healthcare insurance among U.S. refugees only or among U.S. refugees, and immigrants and/or asylum seekers, and published between 2005 and 2018 were included. Primary research, systematic review, and meta-analysis using either quantitative or qualitative data were included. Refugees at different age ranges were included. Articles only addressed immigrants' or asylum seekers' healthcareinsurance in eithertheU.S. or othercountries, were excluded.

\section{Search Strategy}

"Health insurance and refugees in the US" was used as the search phrase. More than 400 peer-reviewed journal articles, book chapters, and reports published during 2005-2018 were reviewed. Only 14 peerreviewed journal articles through major databases, including EBSCO, CINAHL Plus, PubMed, Medline, Medline Plus, and Google Scholar explicitly discussed healthcare insurance among U.S. refugees either quantitatively or qualitatively were included in the final data analysis. Articles only focused on U.S. immigrants were not included.

\section{Data Extraction and Synthesis}

Data was extracted from the 14 peer-reviewed journal articles and synthesized based on the themes, which were related to U.S. refugees access to health insurance and healthcare. Results were presented both quantitatively and qualitatively. [9]. A chart review of 66 adult Bhutanese refugee patients during other chronic health conditions (e.g., dizziness, arthritis, swelling/

\section{Results}

Table 1 presents an overview of major findings from 14 peerreviewed journal articles published between 2005 and 2018, which are related to U.S. refugees, healthcare access, and health insurance. There were 11 primary research articles and three review articles. Seven themes emerged from the current literature review: (1) Compared to the general or minority populations, U.S. refugees were more likely to be uninsured or underinsured [21, 23-35]. Refugees indicated a significant low level of socio-economic status, which prevented them from being insured or fully-insured [21, 23-35]. It was common that a refugee household earned less than $\$ 15,000$ annually. Rarely did a refugee family earn more than $\$ 35,000$ per year [21, 23, 24]. Refugee Medical Assistance (RMA) program only covered refugees' healthcare for the first 8 months of their arrival, and often time, medical professionals were reluctant to accept RMA or charity care [25]. For example, Arab refugees became uninsured after initial months of government assistance, and medical costs had to be paid by out of pocket with a low-pay employment [26]. Many refugee participants also mentioned that they lost state-offered Medicaid [27]. One study indicated that approximately $44 \%$ of U.S. refugees did not expand Medicaid, which resulted in a high rate of uninsured medical visits [28]. Even with refugees who were employed, health insurance was often not available through their employment [29, 30]. Moreover, lack of job security brought refugees a huge concern of themselves losing health insurance at any time [27, 31]. Elwell et al. found out in their study that $95.3 \%$ of refugees within three months of arrival in the U.S. were unemployed; $100 \%$ of refugees were unemployed after living in the U.S. for more than 3 months but less than 8 months; and $70.4 \%$ was unemployed after living in the U.S. for more than 8 months [31]. Furthermore, nearly half of the refugees with chronic health conditions reported being uninsured [30]. (2) Refugees demonstrated the unaffordability of medical co-payments $[27,29,32]$. As one study participant described, a Bhutanese family was shocked by the size of their medical bill after an emergency surgery and treatment [27]. About $69 \%$ of refugees in a study reported that they could not afford their monthly medical bills [32]. (3) There was a lack of full coverage of medical needs [21, 25, 28, 29]. Only $38 \%$ of Sudanese refugees in a study reported they had dental coverage, and $27 \%$ reported pharmacy coverage. About $36 \%$ of Sudanese refugees could cover their prescription costs through Medicaid, however, 30\% paid out of pocket [21]. Consistently, barriers to health insurance coverage were particularly predominant among low-income refugee families [28]. (4) There was a lack of affordable private insurance plans $[24,27,30]$. Compared to other immigrants, refugees were more likely to rely on public health insurance and less likely to afford private insurance [30]. Most refugees could not afford private health insurance [27]. In Misra et al. study, although $61 \%$ of refugee participants had some forms of healthcare coverage, majority of them had a "gold card," which referred to a county indigent care program for refugees to access county health resources. Only 2 participants had insurance through their employment [24]. (5) There was a lack of understanding of the U.S. health insurance application [29, 33, 34]. Refugees were often challenged by the health insurance application process. They illustrated the hardship of enrollment of public insurance programs [29] as well as filling out the insurance applications and healthcare forms [33]. Many refugees failed to follow the U.S. health insurance procedures. For instance, Medicaid required reapplication on a biannual or annual basis. Refugees easily lost their insurance coverage due to missing the reapplication deadline [34]. (6) U.S. refugees struggled to navigate both government and private health insurance [35]. Some refugee informants stated that refugees were not even aware that there were insurance programs that can cover their medical expenditures [35]. And (7) Refugees had difficulties in understanding the U.S. healthcare policies $[25,28,33]$. One Somali refugee described that she was going in and out of her health insurance because she did not understand the insurance policies [33]. Refugees had limited knowledge of health insurance regulations so they did not know what they could expect from having an insurance plan [25], which became a significant problem when the Affordable Care Act (ACA) was being promoted to the refugees [28]. 


\begin{tabular}{|c|c|c|}
\hline Author(s)/ Date of Publication & Study Purpose/Study Population & Key Finings* \\
\hline $\begin{array}{l}\text { Marshall GN, Berthold SM, Schell } \\
\text { TL, Elliott MN, Chun CA, et al. } \\
\text { (2006) }\end{array}$ & $\begin{array}{l}\text { Examine the rates of mental health } \\
\text { seeking behavior and its correlated } \\
\text { factors. A stratified random sample of } 339 \\
\text { Cambodian refugee adults living in Long } \\
\text { Beach, California with Post-Traumatic } \\
\text { Stress Disorder (PTSD), major depression } \\
\text { disorder, or alcohol use disorder }\end{array}$ & $\begin{array}{l}\text { 1. "Most lived in poverty, received } \\
\text { government assistance, and about } 91 \% \text { had } \\
\text { some form of health insurance." }\end{array}$ \\
\hline Willis MS, Nkwocha O (2006) & $\begin{array}{l}\text { Identify Sudanese refugee community's } \\
\text { health needs; inform the service providers; } \\
\text { and advocate for a policy change for } \\
\text { refugee health screening } 263 \text { Sudanese } \\
\text { refugee adults from both Lincoln, Lancaster } \\
\text { County and Omaha, Douglas County of } \\
\text { Nebraska. }\end{array}$ & $\begin{array}{l}\text { 1. "Among } 107 \text { refugee respondents }(40 \%) \text {, } \\
\text { household incomes were less than } \$ 15,000 \\
\text { per annum. } 16 \% \text { households earned } \\
\$ 15,000 \text { but less than } \$ 25,000.2 \% \text { earned } \\
\text { more than } \$ 35,000 \text { each year." } \\
\text { 2. "Refugees have significantly lower } \\
\text { proportional rates of health insurance } \\
\text { coverage compared to either the general } \\
\text { or minority populations }(p=0.00) \text {. Only } \\
60 \% \text { of the refugees in this study have } \\
\text { a current health care plan. Just } 38 \% \text { of } \\
\text { the refugees from Sudan report dental } \\
\text { coverage. Similarly, } 27 \% \text { of the refugees } \\
\text { report pharmacy coverage through a work } \\
\text { plan. Another } 36 \% \text { cover prescription costs } \\
\text { with Medicaid and } 30 \% \text { use cash to cover } \\
\text { pharmacy-related costs." }\end{array}$ \\
\hline Othieno J (2007) & $\begin{array}{l}\text { Examine the barriers to healthcare of } \\
\text { treating HIV among African immigrants } \\
\text { and refugees through the Rapid Assessment, } \\
\text { Response, and Evaluation (RARE) 5 } \\
\text { African immigrant and refugee adult } \\
\text { patients and } 35 \text { individual interviews and } \\
8 \text { focus groups with adult refugee cultural } \\
\text { experts including religious leaders from } \\
\text { the Twin Cities, Minnesota. Participants } \\
\text { came from Countries including Cameroon, } \\
\text { Kenya, Liberia, Uganda, Ethiopia, Somalia, } \\
\text { Sierra Leone, Nigeria, and Tanzania. }\end{array}$ & $\begin{array}{l}\text { 1. "Cultural experts stated that most African } \\
\text { PLWH are also not aware that there are } \\
\text { programs that can pay for medication. Even } \\
\text { in cases in which employers are able to pay } \\
\text { for insurance, there is fear that if people } \\
\text { disclose their HIV status, they may lose their } \\
\text { jobs. At times, people have even claimed } \\
\text { that they had personal health insurance } \\
\text { already to avoid having deductions } \\
\text { taken from their already meager pay." } \\
\text { 2. "Discussing the difficulties faced by } \\
\text { women, Somali cultural experts said } \\
\text { that women may not seek care because } \\
\text { they do not have as many resources } \\
\text { readily available to them as men (such } \\
\text { as education and driving skills). Others } \\
\text { felt that women with children would } \\
\text { not seek care due to insurance costs." }\end{array}$ \\
\hline $\begin{array}{l}\text { Morris MD, Popper ST, Rodwell } \\
\text { TC, Brodine SK, Brouwer KC } \\
(2009)\end{array}$ & $\begin{array}{l}\text { Examine refugees' health condition and the } \\
\text { structural and social barriers to healthcare } \\
\text { services faced by refugees } 40 \text { adult refugee } \\
\text { informants from Albania, Ethiopia, Iraq, } \\
\text { Poland, Somalia, Sudan, and Vietnam, } \\
\text { employees of voluntary resettlement } \\
\text { agencies, personnel of mutual assistance } \\
\text { agencies, and refugee service providers, } \\
\text { living in San Diego County, California }\end{array}$ & $\begin{array}{l}\text { 1. "Barriers related to insurance included } \\
\text { gaps in coverage due to hurdles with } \\
\text { enrollment of public insurance programs or } \\
\text { unavailability through one's employment. } \\
\text { Financial hardship was also a dominant } \\
\text { barrier within this theme-specifically } \\
\text { the financial burden of insurance fees, } \\
\text { co-payments, and out of coverage } \\
\text { prescriptions." }\end{array}$ \\
\hline $\begin{array}{l}\text { Patil CL, McGown M, Nahayo } \\
\text { PD, Hadley C (2010) }\end{array}$ & $\begin{array}{l}\text { Examine individual and structural factors } \\
\text { that impact refugees' diet and mental and } \\
\text { physical well-being } 30 \text { refugees adults } \\
\text { from Bhutan, Liberia, and Somalia living } \\
\text { in Midwest }\end{array}$ & $\begin{array}{l}\text { 1. "Fortunately the bills associated with } \\
\text { Neena's miscarriage were covered by } \\
\text { her insurance. But because she lost her } \\
\text { job cleaning at the hotels, she was no } \\
\text { longer insured; they both worried about } \\
\text { what could happen in the future. With } \\
\text { some pensiveness, Neena told us a story } \\
\text { about another Bhutanese family who was } \\
\text { shocked at the size of the bill they received } \\
\text { after emergency surgery and treatment." } \\
\text { 2. "Many respondents talked about losing } \\
\text { state-offered Medicaid. will become } \\
\text { underinsured or uninsured-most cannot }\end{array}$ \\
\hline
\end{tabular}

Table 1: Cont. 


\begin{tabular}{|c|c|c|}
\hline & & $\begin{array}{l}\text { afford private health insurance. Fear } \\
\text { of healthcare costs, is one reason that } \\
\text { refugees avoid or delay getting treatment; } \\
\text { Chandra and Neena were no exception." }\end{array}$ \\
\hline Pavlish CL, Noor S, Brandt J (2010) & $\begin{array}{l}\text { Examine the health disparities among } \\
\text { Somali refugees and their interactions with } \\
\text { U.S. healthcare system } 57 \text { Somali adult } \\
\text { refugee women and } 13 \text { key informants } \\
\text { from the Minnesota Department of } \\
\text { Health, local non-governmental refugee } \\
\text { assistance organizations, and local health } \\
\text { care organizations in Minnesota }\end{array}$ & $\begin{array}{l}\text { 1. "Several participants in three focus } \\
\text { groups described difficulty understanding } \\
\text { insurance applications and healthcare } \\
\text { forms. One Somali participant described } \\
\text { 'going in and out of insurance because I } \\
\text { don't understand the policies.' Women } \\
\text { described receiving healthcare forms } \\
\text { in the Somali language, but since some } \\
\text { cannot read, 'It's [translation] not helpful.' } \\
\text { Waiting for application approvals was also } \\
\text { difficult. One woman stated, 'I asked for } \\
\text { assistance for all my medications, but the } \\
\text { office told me, 'It's a process. You have to } \\
\text { wait until it goes through.'"' }\end{array}$ \\
\hline Eckstein B (2011) & $\begin{array}{l}\text { Examine the common health issues among } \\
\text { refugees and provide primary healthcare } \\
\text { providers with a guide Systematic review } \\
\text { of current literature; general refugee } \\
\text { populations in the U.S. }\end{array}$ & $\begin{array}{l}\text { 1. "Finally, many refugees do not } \\
\text { understand the U.S. health insurance } \\
\text { process. In States in which Medicaid } \\
\text { requires reapplication on a biannual } \\
\text { or annual basis, many refugees have a } \\
\text { lapse in insurance coverage because they } \\
\text { missed the reapplication deadline." }\end{array}$ \\
\hline Inhorn MC, Serour GI (2011) & $\begin{array}{l}\text { Examine the barriers, including cultural } \\
\text { barriers, to healthcare in the U.S. among } \\
\text { Arab-Muslim refugee patients. } 24 \text { articles } \\
\text { published after September 11, } 2001 \text { in } \\
\text { English about Arab-Muslim refugees' } \\
\text { health and access to healthcare were } \\
\text { included in the review; general Arab- } \\
\text { Muslim refugees and immigrants, and } \\
\text { Muslim patients in the U.S. }\end{array}$ & $\begin{array}{l}\text { 1. "Lack of health insurance: Arab } \\
\text { immigrants are often not insured after } \\
\text { initial months of refugee assistance; } \\
\text { Medical care paid out-of-pocket by Arab } \\
\text { immigrants in low-pay employment, so } \\
\text { most health care is unaffordable; Reliance } \\
\text { on charity for catastrophic coverage; } \\
\text { Inability to return to war-torn countries to } \\
\text { access affordable medical care." }\end{array}$ \\
\hline $\begin{array}{l}\text { Yun K, Fuentes-Afflick E, Desai MM } \\
(2012)\end{array}$ & $\begin{array}{l}\text { Examine the prevalence of chronic } \\
\text { disease and insurance coverage among } \\
\text { U.S. refugees after their immediate post- } \\
\text { arrival period; test the hypothesis that } \\
\text { refugees had higher prevalence of chronic } \\
\text { disease and lower insurance coverage } \\
\text { than other U.S. immigrants } 490 \text { U.S. } \\
\text { adults refugees from Europe and Central } \\
\text { Asia, Latin America and Caribbean and } \\
\text { Africa compared with } 3,715 \text { U.S. adult } \\
\text { immigrants from Latin America and } \\
\text { Caribbean, Asia, and Europe }\end{array}$ & $\begin{array}{l}\text { 1. "Nearly half of refugees and other } \\
\text { immigrants in this sample were uninsured } \\
(49.0 \text { and } 47.4 \% \text {, respectively). Refugees } \\
\text { were less likely to have private insurance } \\
(34.8 \text { vs. } 47.8 \%, P<0.001) \text { and more likely } \\
\text { to have public insurance }(16.2 \text { vs. } 4.8 \% \text {, } \\
\mathrm{P}<0.001) \text { than other immigrants. Nearly } \\
\text { one-quarter }(23.1 \%) \text { of uninsured refugees } \\
\text { reported at least one chronic condition." } \\
2 . \text { "Furthermore, } 46.5 \% \text { of refugees with } \\
\text { any chronic condition reported being } \\
\text { uninsured (data not shown). The majority } \\
\text { of uninsured refugees }(87.6 \%) \text { were from } \\
\text { households in which either the primary } \\
\text { immigrant or the spouse was employed. } \\
\text { In these households, the median } \\
\text { household income was } \$ 24,500 \text { (data not } \\
\text { shown). After adjusting for differences } \\
\text { in socioeconomic variables and health } \\
\text { status, refugees remained less likely to } \\
\text { have private insurance and more likely to } \\
\text { have public health insurance." }\end{array}$ \\
\hline $\begin{array}{l}\text { Elwell D, Junker S, Sillau S, Aagaard E } \\
\text { (2014) }\end{array}$ & $\begin{array}{l}\text { Examine the barriers and gaps to healthcare } \\
\text { services among the Denver refugee } \\
\text { community and provide recommendations } \\
\text { for improvement and advocacy } 64 \text { refugee } \\
\text { adults who arrived in Denver, Colorado } \\
\text { within three months of enrollment in the } \\
\text { study and were attending the Refugee } \\
\text { Clinic at the Lowry Family Health Center }\end{array}$ & $\begin{array}{l}\text { 1. "The two most common reasons cited } \\
\text { for not seeking medical attention for a } \\
\text { problematic mouth was not being able to } \\
\text { afford it }(24 \%) \text { and not having insurance } \\
(22 \%) . " \\
\text { 2. " } 95.3 \% \text { of new arrival refugees are } \\
\text { unemployed, } 100 \% \text { for supported refugees, } \\
\text { and } 70.4 \% \text { for established refugees." }\end{array}$ \\
\hline
\end{tabular}

Table 1: Cont........... 


\begin{tabular}{|c|c|c|}
\hline Author(s)/ Date of Publication & Study Purpose/Study Population & Key Finings* \\
\hline & $\begin{array}{l}\text { for either their first or second visit were in } \\
\text { the New Arrival group; } 28 \text { refugee adults } \\
\text { who arrived in the Denver Metro Area } \\
\text { within eight months of enrollment in the } \\
\text { study and were supported by a local refugee } \\
\text { volunteer agency at the time of enrollment } \\
\text { were in the Support group; } 28 \text { refugee } \\
\text { adults who lived in the Denver Metro Area } \\
\text { for longer than eight months at the time of } \\
\text { enrollment were in the Established group; } \\
\text { Participants were from Asia, Middle East, } \\
\text { Africa, and Europe }\end{array}$ & $\begin{array}{l}\text { 3. "Fifty- five percent of new arrival } \\
\text { refugees reported health insurance. } \\
\text { This number increased to } 89 \% \text { among } \\
\text { supported refugees. However, only } 37 \% \\
\text { of established refugees reported health } \\
\text { insurance }(p<.001) \text {. Overall, established } \\
\text { refugees were less likely to report health } \\
\text { insurance than refugees who arrived less } \\
\text { than eight months ago (OR } 0.31,95 \% \text { CI } \\
0.13-0.76 \text {, p- value =.009)." }\end{array}$ \\
\hline $\begin{array}{l}\text { Mirza M, Luna R, Mathews B, } \\
\text { Hasnain R, Hebert E, et al. (2014) }\end{array}$ & $\begin{array}{l}\text { Examine the barriers to healthcare access } \\
\text { among newly resettled disabled and } \\
\text { chronically ill U.S. refugees; Develop } \\
\text { a Community Advisory Board; Engage } \\
\text { the Board to identify research needs and } \\
\text { develop research agenda } 18 \text { adult key } \\
\text { informants including representatives from } \\
\text { state Bureau of Refugee and Immigrant } \\
\text { Services and Department of Public } \\
\text { Health, refugees healthcare providers, and } \\
\text { community leaders from the three largest } \\
\text { refugee groups since } 2008 \text { (Iraqi, Burmese, } \\
\text { and Bhutanese) }\end{array}$ & $\begin{array}{l}\text { 1. "System level barriers: Refugee Medical } \\
\text { Assistance (RMA) coverage limit to } 8 \\
\text { months; funding shortage; Supplemental } \\
\text { Security Income (SSI) denials." } \\
\text { 2. "Providers level barriers: Medical } \\
\text { specialists reluctant to accept RMA/charity } \\
\text { care; limited awareness and capacity } \\
\text { among refugee service provides." } \\
\text { 3. "Individual level barriers: limited } \\
\text { awareness of insurance regulations; don't } \\
\text { know what to expect." }\end{array}$ \\
\hline $\begin{array}{l}\text { Navuluri N, Haring A, Smithson- } \\
\text { Riniker K, Sosland R, Vivanco R, } \\
\text { et al. (2014) }\end{array}$ & $\begin{array}{l}\text { Examine the differences in healthcare } \\
\text { barriers including structural barriers among } \\
\text { refugee groups from different countries } \\
\text { A random sample of } 49 \text { refugee adults from } \\
\text { Bhutan, Nepal, Iraqi, Iran, Burma, Burundi, } \\
\text { Congo, Cameroon, and Sri Lanka, living in } \\
\text { San Antonio, Texas }\end{array}$ & $\begin{array}{l}\text { 1. " } 47.7 \% \text { of our study population } \\
\text { reported being unemployed and } 69 \% \\
\text { of refugees reported that they could not } \\
\text { pay their medical bills every month. } \\
\text { Interestingly, } 79.1 \% \text { of respondents } \\
\text { reported having some current form of } \\
\text { health payment system or insurance." }\end{array}$ \\
\hline $\begin{array}{l}\text { Pace M, Al-Obaydi S, Nourian } \\
\text { MM, Kamimura A (2015) }\end{array}$ & $\begin{array}{l}\text { Examine the limitations of U.S. federal } \\
\text { health policies related to refugees' } \\
\text { health including health insurance, health } \\
\text { screening, health promotion, and Survivor } \\
\text { of Torture Program, and suggest for } \\
\text { improvement. } \\
\text { A policy review; general refugee population } \\
\text { in the U.S. }\end{array}$ & $\begin{array}{l}\text { 1. "The percentage of uninsured individuals } \\
\text { decreased from approximately } 18 \% \text { to } 9 \% \\
\text { after the introduction of the Affordable } \\
\text { Care Act (ACA) (Hall \& Lord, 2014). } \\
\text { However, it is predicted that } 36 \text { to } 45 \\
\text { million individuals will still be uninsured } \\
\text { by } 2019 \text { (Geyman, 2015)." } \\
\text { 2. "Low-income families reported barriers } \\
\text { to insurance coverage, access to healthcare } \\
\text { services, and healthcare costs (DeVoe, et } \\
\text { al., 2007). These barriers remain regardless } \\
\text { whether they are eligible for healthcare } \\
\text { coverage through the ACA (Sommers, } \\
\text { Maylone, Nguyen, Blendon, \& Epstein, } \\
\text { 2015). Research indicates that the lack of } \\
\text { knowledge is a significant problem when } \\
\text { promoting enrollment in the ACA insurance } \\
\text { (Evans \& Demko, 2014). Uninsured visits } \\
\text { remain high, especially in states that opted } \\
\text { out of Medicaid expansion (Angier, et al., } \\
\text { 2015). Approximately 44\% of refugees } \\
\text { resettled in a state that did not expand } \\
\text { Medicaid (Agrawal, \& Venkatesh, 2015)." } \\
\text { 3. "Furthermore, refugees may need } \\
\text { expanded health insurance coverage due } \\
\text { to high burden of chronic conditions (Yun, } \\
\text { Fuentes-Afflick, \& Desai, 2012). Even } \\
\text { though refugees are theoretically covered } \\
\text { by health insurance, they still have a risk } \\
\text { for being un- or under- insured." }\end{array}$ \\
\hline
\end{tabular}

Table 1: Cont.. 


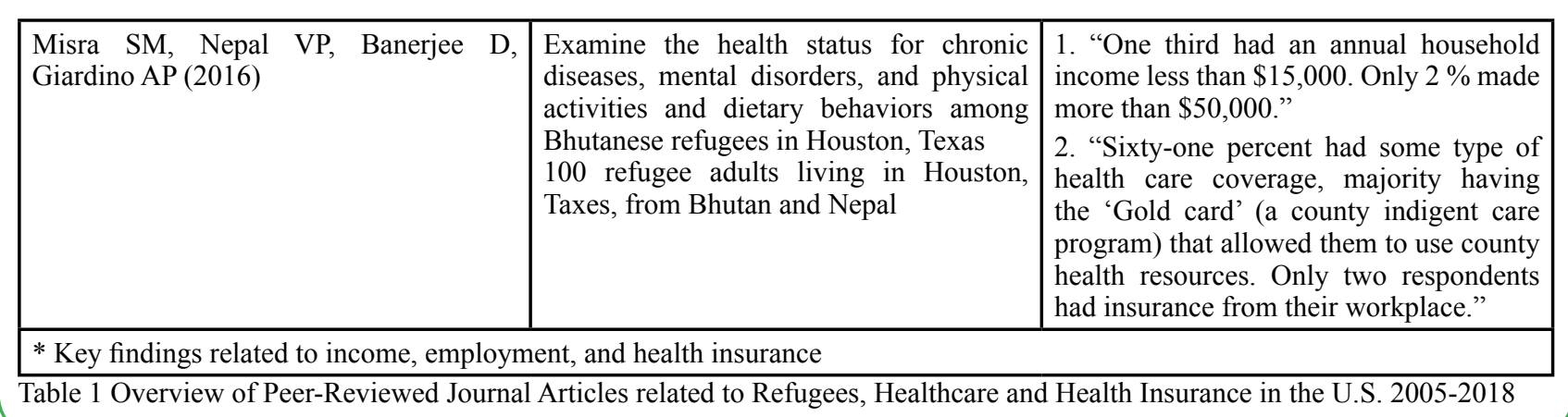

\section{Discussion}

current findings indicated that refugees were more likely to be uninsured or underinsured than the general and minority populations. They consistently struggled with limited insurance coverage, high co-payment, and unaffordability of private insurance plans [21, 2335]. Most refugees are enrolled in RMA for their health insurance for the first eight months in the U.S. Refugee resettlement agencies helps refugees become a member of RMA upon their arrival. After eight months, refugees will have to seek other health insurance programs, such as ACA, to cover their medical expenditures [36]. The ACA aimed to achieve a nearly-universal health care and provide a majority of U.S. citizen and legal residents including refugees with health insurance and quality care at a lower cost and expanded Medicaid coverage [36-40]. By ACA law, U.S. refugees are eligible to purchase health insurance in Health Insurance Exchanges (HIE). Refugees who earn above $133 \%$ of the federal poverty line without either private or employment-based insurance can purchase quality affordable healthcare through HIE. Refugees who earn up to $133 \%$ of the federal poverty level and are under age of 65 are covered by Medicaid [37-40]. However, according to a five-year assessment of ACA implementation, besides the significant gains, by 2019, approximately 36 million out of 50 million uninsured will remain uninsured, and 5 million will still not be covered by Medicaid in states who opted out from Medicaid expansion. The insured, especially newly insured, has been challenged by a limited number of physician and hospital choices because of narrow networks, shortage of primary care physicians, increased medical costs including prescription drug costs, devalued insurance policies and increased insurance premiums. And there is no clear evidence demonstrating that ACA has improved the quality of healthcare [41]. The recent presidential Executive Order also compromised the implementation of ACA. It limited the advertisement of ACA and shortened the open enrollment period; eliminated the government cost-sharing subsides for reducing deductibles and out-of-pocket costs; eliminated the individual mandate, which could increase the number of the uninsured; gave individual state to add more restrictions to Medicaid; encouraged sale of short-term health insurance plans which could exclude buyers with pre-health conditions; and weakened the cost coverage of contraceptive measures [42].

Compared to other immigrants and U.S.-born adults, although U.S. refugees presented a similar or even slightly higher employment rate, refugees had significantly lower occupational status and earnings [43, 44]. Refugees were more likely to live on public welfare, such as food stamps, cash welfare, government health insurance [44]. Refugees' household income also varied by refugees' country of origin and gender. Refugees from countries, including Somalia, Iraq, Burma, Bhutan, Liberia, and Cuba, are more likely to be at an economic disadvantage and live in poverty [44]. Low literacy and education levels, pre-existing mental health issues due to wars and persecution, difficulties in adopting new values and beliefs in a new country, foreign language capacity, low self-efficacy due to immigration stressors, social oppression and discrimination, inconvenience of residential locations, and unacceptance of former trainings prior to immigration, contributed to both occupational and economic disparities among refugees $[44,45]$. A state report by the Maine Department of Labor indicated that although the average earnings of refugees relocated in Maine increased over time, compared to the regular earnings of other workers in Portland, Maine, refugees' earnings remained lower [46]. Most refugees worked for a temporary help services industry with low pay, such as administrative and support services, eating and drinking places, and accommodation industries [46]. Instead of working for a career development, refugees are working for survival [45]. Refugee families' financial constraint was further illustrated by the studies related to food insecurity [47-50]. Earning less than $\$ 2,000$ per month was highly prevalent among refugee households [47, 48]. More than half of the study refugee families were worried about running out of food and/ or lack of money to buy sufficient food. Nearly half of the families had to cut the size of their meals to meet their limited budget [47]. About $98 \%$ of refugee families in a study ever used food stamps, and $48 \%$ of them were still using the food stamps [48]. Approximately $42 \%$ of Liberian refugee households experienced child hunger, and $85 \%$ of them experienced food insecurity [49]. The seriousness of both the economic and occupational disadvantage among U.S. refugees largely accounts for the status of refugees being uninsured or underinsured and stresses the significance of unaffordability and unavailability of health insurance for refugees.

The current review also revealed the refugee populations' concerns about understanding the U.S. health insurance application process, navigating both government and private insurance plans, and understanding the general U.S. healthcare policies $[25,28,29,33-$ 35]. In an effort to respond to these challenges faced by refugees, most recently, the International Refugee Committee in Denver, Colorado, implemented a new pilot program, entitled "Engaging refugees in their health coverage options," to help refugees navigate the U.S. healthcare system including health insurance system and improve refugees' insurance literacy. The Program aimed to provide refugees, especially newly-arrived refugees, with individualized support, and culturally and linguistically competent knowledge and skills to empower refugees to successfully navigate local health insurance exchange programs, to retain their health insurance plans, and enhance their understanding of how changes made to the healthcare system can impact each individual refugee's health insurance coverage [51]. United Nations High Commissioner for Refugees (UNHCR)'s guidance note on health insurance schemes for refugees and other persons of concern to UNHCR also identified six strategies to expand refugee populations' health insurance access worldwide, including not only adopting "innovative enrollment strategies, improving management and organization of health insurance programs, improving healthcare delivery, and increasing 
public awareness" but also making refugees more eligible to health insurance plans and making premiums more affable to them [52]. The Guidance emphasized the consideration of refugees' socio-economic status in strategizing health insurance programs, prioritizing the types of medical expenses for coverage, and sustaining refugees' healthcare; emphasized the importance of continuing advocacy on behalf of refugees in assuring refugees' access to healthcare in their resettlement countries [52].

\section{Conclusions}

As suggested by the current literature, in general, U.S. refugees struggle to obtain and retain their health insurance because of both individual and contextual disadvantages [21, 23-35]. However, there is a significant lack of research specifically looks into the essentials of both accessibility and affordability of health insurance among multiethnic refugee populations in the U.S., and how exactly refugees' country of origin, gender, and socio-economic status, including employment, occupation, income, and education, has factored in their insurance buying-power in the short-term and the long-term. More research is needed to examine such as how refugee individuals and their families have been prioritizing their medical expenditures, including expenses on chronic diseases and preventive care; how accessible the care has been with their current health insurance; and how ACA has impacted on refugees' health insurance and healthcare access after its implementation. Data are vital to support a healthcare policy change.

\section{References}

1. Lifson AR, Thai D, O'fallon A, Mills WA, Hang K et al. (2002) Prevalence of tuberculosis, hepatitis B virus, and intestinal parasitic infections among refugees to Minnesota. Public Health Rep 119: 69-77.

2. Liu Y, Weinberg MS, Ortega LS, Painter JA, Maloney SA et al. (2009) Overseas screening for tuberculosis in US-bound immigrants and refugees. New Eng J Med 360: 2406-2415.

3. Scott KC, Taylor EM, Mamo B, Herr ND, Cronkright PJ, et al. (2015) Hepatitis B screening and prevalence among resettled refugees-United States. 2006-2011. MMWR 64: 570-573.

4. Yun K, Hebrank K, Graber LK, Sullivan MC, Chen I et al. (2012) High prevalence of chronic non-communicable conditions among adult refugees: Implications for practice and policy. J Community Health 37: 1110-1118.

5. Yun K, Fuentes-Afflick E, Desai MM (2012) Prevalence of chronic disease and insurance coverage among refugees in the United States. J Iimmigr Minor Health 14: 933-940.

6. Yun K, Mohamad Z, Kiss L, Annamalai A, Zimmerman C et al. (2016) History of persecution and health outcomes among U.S. refugees. J Iimmigr Minor Health 18: 263-269.

7. Fennelly K (2006) Listening to the experts: provider recommendations on the health needs of immigrants and refugees. Journal of Cult Divers 13: 190-201.

8. Mishori R, Aleinikoff S, Davis D (2017) Primary care for refugees: Challenges and opportunities. Am Fam Physician 96: $112-120$.

9. Bhatta MP, Shakya S, Assad L, Zullo MD (2015) Chronic disease burden among Bhutanese refugee women aged 18-65 years resettled in Northeast Ohio, United States, 2008-2011. J Iimmigr Minor Health 17: 1169-1196.

10. Kumar GS, Varma S, Saenger MS, Burleson M, Kohrt BA et al. (2014) Noninfectious disease among the Bhutanese refugee population at a United States urban clinic. J Iimmigr Minor Health 16: 922-925.

11. Misra SM, Nepal VP, Banerjee D, Giardino AP (2016) Chronic health conditions, physical activity and dietary behaviors of Bhutanese refugees: a Houston-based needs assessment. J Iimmigr Minor Health 18: 1423-1431.
12. Hagaman AK, Sivilli TI, Ao T, Blanton C, Ellis H et al. (2016) An investigation into suicides among Bhutanese refugees resettled in the United States between 2008 and 2011. J Iimmigr Minor Health 18: 819-827.

13. Ao T, Shetty S, Sivilli T, Blanton C, Ellis H et al. (2016) Suicidal ideation and mental health of Bhutanese refugees in the United States. J Iimmigr Minor Health 18: 828-835.

14. Willard CL, Rabin M, Lawless M (2014) The prevalence of torture and associated symptoms in United States Iraqi refugees. J Iimmigr Minor Health 16: 1069-1076.

15. Taylor EM, Yanni EA, Pezzi C, Guterbock M, Rothney E et al. (2014) Physical and mental health status of Iraqi refugees resettled in the United States. J Iimmigr Minor Health 16: 11301137.

16. Jamil H, Nassar-McMillan S, Lambert R, Wang Y, Ager J et al. (2010) Pre-and post-displacement stressors and time of migration as related to self-rated health among Iraqi immigrants and refugees in Southeast Michigan. Med Confl Surviv 26: 207222.

17. Jen KL, Zhou K, Arnetz B, Jamil H (2015) Pre-and postdisplacement stressors and body weight development in Iraqi refugees in Michigan. J Iimmigr Minor Health 17: 1468-1475.

18. Yanni EA, Naoum M, Odeh N, Han P, Coleman M et al. (2013) The health profile and chronic diseases comorbidities of USbound Iraqi refugees screened by the International Organization for Migration in Jordan: 2007-2009. J Iimmigr Minor Health 15: $1-9$.

19. Marshall GN, Schell TL, Wong EC, Berthold SM, Hambarsoomian K, et al. (2016) Diabetes and cardiovascular disease risk in Cambodian refugees. J Iimmigr Minor Health 18: $110-119$

20. Wong EC, Marshall GN, Schell TL, Elliott MN, Babey S et al.(2011) The unusually poor physical health status of Cambodian refugees two decades after resettlement. J Iimmigr Minor Health 13: 876-882.

21. Willis MS, Nkwocha O (2006) Health and related factors for Sudanese refugees in Nebraska. J Iimmigr Minor Health 8: 1933.

22. Wagner J, Burke G, Kuoch T, Scully M, Armeli S et al. (2013) Trauma, healthcare access, and health outcomes among Southeast Asian refugees in Connecticut. J Iimmigr Minor Health 15: 1065-1072.

23. Marshall GN, Berthold SM, Schell TL, Elliott MN, Chun CA, et al. (2006) Rates and correlates of seeking mental health services among Cambodian refugees. Am J Public Health 96: 1829-1835.

24. Misra SM, Nepal VP, Banerjee D, Giardino AP (2016) Chronic health conditions, physical activity and dietary behaviors of Bhutanese refugees: a Houston-based needs assessment. J Iimmigr Minor Health 18: 1423-1431.

25. Mirza M, Luna R, Mathews B, Hasnain R, Hebert E et al. (2014) Barriers to healthcare access among refugees with disabilities and chronic health conditions resettled in the US Midwest. J Iimmigr Minor Health 16: 733-742.

26. Inhorn MC, Serour GI (2011) Islam, medicine, and ArabMuslim refugee health in America after 9/11. The Lancet 378: 935-943.

27. Patil CL, McGown M, Nahayo PD, Hadley C (2010) Forced migration: Complexities in food and health for refugees resettled in the United States. Ann Anthropol Pract 34: 141-160. 
28. Pace M, Al-Obaydi S, Nourian MM, Kamimura A (2015) Health services for refugees in the United States: policies and recommendations. Health 5: 63-68.

29. Morris MD, Popper ST, Rodwell TC, Brodine SK, Brouwer KC et al. (2009) Healthcare barriers of refugees post-resettlement. J Community Health 34: 529-538.

30. Yun K, Fuentes-Afflick E, Desai MM (2012) Prevalence of chronic disease and insurance coverage among refugees in the United States. J Iimmigr Minor Health 14: 933-940.

31. Elwell D, Junker S, Sillau S, Aagaard E (2014) Refugees in Denver and their perceptions of their health and health care. $\mathrm{J}$ Health Care Poor Underserved 25: 128-141.

32. Navuluri N, Haring A, Smithson-Riniker K, Sosland R, Vivanco $R$, et al. (2014) Assessing Barriers to Healthcare Access Among Refugees Living in San Antonio, Texas. Tex Public Health J 66: 5-9.

33. Pavlish CL, Noor S, Brandt J (2010) Somali immigrant women and the American health care system: discordant beliefs, divergent expectations, and silent worries. Soc Sci Med 71: 353-361.

34. Eckstein B (2011) Primary care for refugees. Am Fam Physician 83: 429-436.

35. Othieno J (2007) Understanding how contextual realities affect African born immigrants and refugees living with HIV in accessing care in the Twin Cities. J Health Care Poor Underserved 18: 170-188.

36. Refugee Center Online. Health insurance for refugees in the United States.

37. Refugee Health Technical Assistance Center. Affordable Care Act.

38. Office of Refugee Resettlement. Health Insurance.

39. Office of the Legislative Counsel. Compilation of Patient Protection and Affordable Care Act.

40. Centers for Medicare \& Medicaid Services. Eligibility.

41. Geyman JP (2015) A five-year assessment of the Affordable Care Act: Market forces still trump the common good in US health care. Int J Health Serv 45:209-225.

42. Cable News Network. 8 ways Trump hurt Obamacare in his first year.

43. Connor P (2010) Explaining the refugee gap: Economic outcomes of refugees versus other immigrants. J Refug Stud 23: 377-397.

44. Capps R, Newland K, Fratzke S, Groves S, Auclair G et al. (2015) Integrating refugees in the United States: The successes and challenges of resettlement in a Global Context. Stat J IAOS 31:341-367.

45. Yakushko O, Backhaus A, Watson M, Ngaruiya K, Gonzalez J et al. (2008) Career development concerns of recent immigrants and refugees. J Career Dev 34(4): 362-396.

46. Allen R. Employment and earnings outcomes for recently arrived refugees in Portland, Maine.

47. Hadley C, Patil CL, Nahayo D (2010) Difficulty in the food environment and the experience of food insecurity among refugees resettled in the United States. Ecol Food Nutr 49: 390407.

48. Hadley C, Zodhiates A, Sellen DW (2007) Acculturation, economics and food insecurity among refugees resettled in the USA: A case study of West African refugees. Public Health Nutr 10: 405-412.
49. Hadley C, Sellen D (2006) Food security and child hunger among recently resettled Liberian refugees and asylum seekers: a pilot study. J Iimmigr Minor Health 8:369-75.

50. Rondinelli AJ, Morris MD, Rodwell TC, Moser KS, Paida P, et al. (2011) Under-and over-nutrition among refugees in San Diego County, California. J Iimmigr Minor Health. 13: 161168.

51. International Rescue Committee. New program in Denver helps refugees navigate the U.S. healthcare system.

52. United Nation High Commissioner for Refugees. A guidance note on health insurance schemes for refugees and other persons of concern to UNHCR. 